\title{
Uric acid as an important biomarker in hypertensive disorders in pregnancy
}

\author{
Triveni Kondareddy*, Prathap T.
}

Department of Obstetrics and Gynecology, JSS Medical College, Mysore, Karnataka, India

Received: 05 October 2016

Accepted: 02 November 2016

\section{*Correspondence:}

Dr. Triveni Kondareddy,

E-mail: triveni.kondareddy@gmail.com

Copyright: () the author(s), publisher and licensee Medip Academy. This is an open-access article distributed under the terms of the Creative Commons Attribution Non-Commercial License, which permits unrestricted non-commercial use, distribution, and reproduction in any medium, provided the original work is properly cited.

\section{ABSTRACT}

Background: Hypertension in pregnancy is a global problem and complicates approximately 10-17\% of pregnancies. The incidence of PIH in India ranges from 5\% to $15 \%$. Uric acid is a marker of oxidative stress, tissue injury and renal dysfunction and therefore might be helpful in the prediction of complications of PE. Literature on serum uric acid as a predictor of complications of PE is conflicting. The present is intended to study uric acid as an important biomarker in hypertension in pregnancy.

Methods: This was prospective observational analytical case control study of 180 individuals done at JSS Hospital, Mysore, India from January 2015 to July 2016.

Results: A positive correlation was observed between rise in uric acid and severity of hypertension in pregnancy ( $\mathrm{p}<0.01$ ). Hypertensive mothers with uric acid levels $>6.0 \mathrm{mg} / \mathrm{dl}$ shows $100 \%$ maternal deaths, $79.4 \%$ with eclampsia and $71.9 \%$ with preterm delivery.

Conclusions: A positive correlation was observed between rise in uric acid and severity of hypertension in pregnancy. Hyperuricemia in patients with hypertensive disorders of pregnancy is a strong risk factor for several maternal and perinatal complications.

Keywords: Eclampsia, Maternal outcome, Pre-eclampsia, Perinatal outcome, Uric acid

\section{INTRODUCTION}

Preeclampsia is defined as a multisystem disorder occuring in pregnancy and the puerperium which is characterized by development of hypertension of 140/90 $\mathrm{mmHg}$ and above after the 20th week in a previously normotensive patient. ${ }^{1}$ It is a global problem and complicates approximately $10-17 \%$ of pregnancies. The incidence of PIH in India ranges from $5 \%$ to $15 \%$. $^{2}$

$\mathrm{PIH}$ is responsible for $14 \%$ of maternal deaths in the world. ${ }^{3}$ Uric acid is a marker of oxidative stress, tissue injury and renal dysfunction, and therefore might be helpful in the prediction of complications of PE. ${ }^{4}$

Hypoxia and ischemia of the placenta and cytokines such as interferon induce the expression of xanthine oxidase and therefore increase the production of uric acid and also reactive oxygen species. ${ }^{5}$

Literature on serum uric acid as a predictor of complications of PE is conflicting.

Several studies have demonstrated a correlation between elevated maternal serum uric acid levels and adverse maternal and neonatal outcome, where as other studies showed that serum uric acid is a poor predictor of PE. ${ }^{6-14}$ In a recent systematic review on the subject, a raised serum uric acid was associated with an almost doubled risk of severe complications, such as eclampsia, severe hypertension, and perinatal death. ${ }^{15}$ The present is intended to study uric acid as an important biomarker in hypertension in pregnancy. 
Aim of the study was to compare the uric acid in preeclampsia and eclampsia patients with normal pregnancies and to correlate the perinatal maternal and outcome with uric acid in pre-eclampsia and eclampsia.

\section{METHODS}

A prospective observational antenatal cases control study was done at JSS Medical College and Hospital. Mysore, India from January 2015 to July 2016. Healthy normotensive pregnant females in the third trimester of pregnancy, without any signs and symptoms of pregnancy induced hypertension were considered as controls.

Pregnant females in the third trimester with symptoms and signs of pregnancy induced hypertension, admitted in antenatal care ward were selected and grouped as per the criteria described in classification of hypertensive disorders of pregnancy according to the American College of Obstreticians and Gynaecologists. ${ }^{16}$ Total 180 cases were included in the study

\section{The study groups were divided as follows}

- Healthy normotensive pregnant controls $=50$.

- $\quad$ Patients with mild preeclampsia $=50$.

- $\quad$ Patients with severe preeclampsia $=50$.

- $\quad$ Patients with eclampsia $=30$

Under all aseptic precaution samples were collected randomly for uric acid. All relevant clinical details were collected from patients.

\section{Outcome measures}

The maternal outcome was noted in terms of the mode of termination of pregnancy, maternal complications and maternal end result. Fetal outcome was assessed by perinatal morbidity and mortality, need for admission in NICU, and neonatal end result.

\section{RESULTS}

Table 1: Uric acid GP.

\begin{tabular}{|llll|}
\hline Category & $<6$ & $>6$ & Total \\
\hline Normotensives & 50 & 0 & 50 \\
$\%$ & 100.0 & 0.0 & 100.0 \\
\hline Mild pre-eclampsia & 45 & 5 & 50 \\
$\%$ & 90.0 & 10.0 & 100.0 \\
\hline Severe pre-eclampsia & 16 & 34 & 50 \\
$\%$ & 32.0 & 68.0 & 100.0 \\
\hline Eclampsia & 5 & 25 & 30 \\
$\%$ & 16.7 & 83.3 & 100.0 \\
\hline Total & 116 & 64 & 180 \\
\hline
\end{tabular}

Elevated uric acid levels had increased risk of premature delivery than pre eclamptic women whose uric acid levels were normal. Our findings are $100 \%$ maternal deaths, $79.4 \%$ with eclampsia, and $71.9 \%$ with preterm delivery in hypertensive mothers with uric acid levels $>6.0 \mathrm{mg} / \mathrm{dl}$.

Table 2: Uric acid mean values.

\begin{tabular}{|llll|}
\hline & Obs. & Mean & SD \\
\hline Normotensives & 50 & 3.5244 & 0.2396 \\
\hline Mild pre-eclampsia & 50 & 5.5040 & 0.3404 \\
\hline Severe pre-eclampsia & 50 & 6.2590 & 0.3398 \\
\hline Eclampsia & 30 & 7.4300 & 1.1653 \\
\hline
\end{tabular}

Table 3: Maternal outcome.

\begin{tabular}{|lll|}
\hline & Uric acid & \\
\hline & $<\mathbf{6}$ & $\mathbf{2 6}$ \\
\hline Abruption (8) & $1(0.9 \%)$ & $7(87.5 \%)$ \\
\hline ARF (6) & $1(16.7 \%)$ & $5(83.3 \%)$ \\
\hline Eclampsia(34) & $7(20.6 \%)$ & $27(79.4 \%)$ \\
\hline HELLP (11) & $1(9.1 \%)$ & $10(90.9 \%)$ \\
\hline Mortality (1) & 0 & $1(100 \%)$ \\
\hline
\end{tabular}

Table 4: Perinatal outcome.

\begin{tabular}{|lll|}
\hline & Uric acid & \\
\hline & $<\mathbf{6}$ & $\mathbf{2 6}$ \\
\hline IUGR (36) & $19.40 \%$ & $80.60 \%$ \\
\hline Still birth (7) & 0 & $100 \%$ \\
\hline Alive (165) & $65.50 \%$ & $34.50 \%$ \\
\hline NICU (41) & $29.30 \%$ & $70.70 \%$ \\
\hline Preterm (32) & $28.12 \%$ & $71.90 \%$ \\
\hline
\end{tabular}

\section{DISCUSSION}

In our study, the uric acid was very significantly higher in severe preeclampsia $(\mathrm{P}<0.01)$ and eclampsia $(\mathrm{P}<0.01)$ than that in normal healthy pregnant controls. Whereas the uric acid in mild preeclampsia was not significantly higher than the healthy pregnant contro. ${ }^{10}$ In our study, trend of increasing uric acid with increasing severity of pregnancy induced hypertension is consistent and this results are comparable to those of Lim et al, Williams et al. Lim et al study shows the mean serum uric acid values for women with preeclampsia $(6.2 \pm 1.4 \mathrm{mg} / \mathrm{dl})$ and were significantly higher than those of controls $(4.3 \pm 0.8 \mathrm{mg} / \mathrm{dl}$, $\mathrm{p}<0.05)$ which is comparable to our study. ${ }^{17}$ Williams et al concluded uric acid levels significantly elevated in women with gestational hypertension and preeclampsia as compared to normotensive pregnant women which is similar to our study. ${ }^{18}$

According to Mustaphi et al, mean uric acid levels in normotensive women in the antenatal period were $4.65 \pm 0.33$ and in mild $\mathrm{PIH}$ were $5.42 \pm 0.55$ respectively. Level of serum uric acid in mild PIH was significantly higher than normotensive women. In severe PIH, the mean serum uric acid levels were $6.65 \pm 0.60$ in antepartum which was significantly more than control 
group and mild PIH group women which is compared to our study. ${ }^{18}$ In our study, elevated uric acid levels had increased risk of premature delivery than pre-eclamptic women whose uric acid levels were normal. These finding are in agreement to our findings showing $100 \%$ maternal deaths, $79.4 \%$ with eclampsia and $71.9 \%$ with preterm delivery in hypertensive mothers with uric acid levels $>6.0 \mathrm{mg} / \mathrm{dl}$.

Krishna $\mathrm{S}$ et al, Thanna et al, Yalamati $\mathrm{P}$ et al, concluded that high serum uric acid level could be a useful indicator of the maternal and fetal complication which is comparable to our study. ${ }^{20-22}$ Hawkins TL et al, studied of hypertensive pregnant women (those with pre-eclampsia or gestational hypertension) the risk of adverse maternal outcome and adverse fetal outcome increased with increasing concentration of uric acid which is compared to our study. ${ }^{23}$

Funding: No funding sources

Conflict of interest: None declared

Ethical approval: The study was approved by the Institutional Ethics Committee

\section{REFERENCES}

1. Sibai BM. Chronic hypertension in pregnancy. Obstet Gynecol. 2002;100(2):369-77.

2. Anand S, Kirshnanand. Perinatal outcome in growth retarded babies born to normotensive and hypertensive mothers: a prospective study. People J Sci Res. 2012;5:24-8.

3. World Health Organization; Maternal mortality. Available at http:// www.who.int/ mediacentre/ factsheets/ fs 348/ en/. Accessed on 11 July 2016.

4. Powers RW, Bodnar LM, Ness RB. Uric acid concentration in early pregnancy among preeclamptic women with gestational hyperuricemia at delivery. Am J Obstet Gynecol. 2006;194:160.

5. Many A, Hubel CA, Roberts JM. Hyperuricemia and xanthine oxidase in preeclampsia, revisited. Am J Obstet Gynecol. 1996;174:288-91.

6. Liedholm H, Montan S, Aberg A. Risk grouping of 113 patients with hypertensive disorders during pregnancy, with respect to serum urate, proteinuria and time of onset of hypertension. Acta Obstet Gynecol Scand Suppl. 1984;118:43-8.

7. Redman CW, Beilin LJ, Bonnar J, Wilkinson RH. Plasma-urate measurements in predicting fetal death in hypertensive pregnancy. Lancet. 1976;1:1370-3.

8. Lancet M, Fisher IL. The value of blood uric acid levels in toxaemia of pregnancy. J Obstet Gynaecol Br Emp. 1956;63:116-9.
9. Mcfarlane CN. An evaluation of the serum uric acid level in pregnancy. J Obstet Gynaecol Br Common. 1963;70:63-8.

10. Martin JN, May WL, Magann EF, Terrone DA, Rinehart BK, Blake PG. Early risk assessment of severe preeclampsia: admission battery of symptoms and laboratory tests to predict likelihood of subsequent significant maternal morbidity. Am J Obstet Gynecol. 1999;180:1407-14.

11. Roberts JM, Bodnar LM, Lain KY. Uric acid is as important as proteinuria in identifying fetal risk in women with gestational hypertension. Hypertension. 2005;46:1263-9.

12. Dekker GA, Sibai BM. Early detection of preeclampsia. Am J Obstet Gynecol. 1991;165:160-72.

13. Agudelo CA, Lede R, Belizan J. Evaluation of methods used in the prediction of hypertensive disorders of pregnancy. Obstet Gynecol Surv. 1994;49:210-22.

14. Williams KP, Galerneau F. The role of serum uric acid as a prognostic indicator of the severity of maternal and fetal complications in hypertensive pregnancies. J Obstet Gynaecol Can. 2002;24:628-32.

15. Thangaratinam S, Ismail KMK, Sharp S, Coomarasamy A, Khan KS. Accuracy of serum uric acid in predicting complications of pre-eclampsia: a systemic review. BJOG. 2006;113:369-78.

16. Practice guidelines ACOG practice bulletin on diagnosing and managing preeclampsia and eclampsia. Available at http:// www.aafp.org /afp/ 2002/0715/p330. Accessed on 12 July 2016.

17. Lim KH, Friedman SA, Ecker JL, Kao L, Kilpatrick SJ. The clinical utility of serum uric acid measurements in hypertensive diseases of pregnancy. Am J Obstet Gynecol. 1998;178(5):1067-71.

18. Williams KP, Galerneau F. The role of serum uric acid as aprognostic indicator of the severity of maternal and fetal complication in hypertensive pregnancy. Can J Obstet Gyncol. 2002;24(8):628-32

19. Rahman M, Gopalan S, Dhaliwal L. Hyperuricemia and PIH- reappraisal. Indian J Med Sci. 1996;50(3):68-71.

20. Krishna TS, Krishnamma M, Rajeswari DR, Rao V, Naidu JN, et al. Alterations of serum uric acid concetrations in preeclampsia. Int $\mathrm{J}$ Applied Bio Pharmaceutical Tech. 2015;6(2):165-7.

21. Thanna RC, Choudhary R, Pathak S, Vamne A, Nigoskaret S. Level of serum acid in preeclampsia. International J Clinical Biochem. 2015;2(2):120-2.

22. Yalamati P, Bhongir AV, Betha K, Verma R, Dandge S. Relationship of serum uric acid, serum creatinine and serum cystatin $\mathrm{C}$ with maternal and fetal outcomes in rural Indian pregnant women. Int J Reprod Contracept Obstet Gynecol. 2015;4(5):1505-10.

23. Hawkins TL, Roberts LM, Brown MA. Plasma uric acid remains a marker of poor outcome in hypertensive pregnancy: a retrospective cohort study. BJOG. 2012;119(4):484-92.

Cite this article as: Kondareddy T, Prathap T. Uric acid as an important biomarker in hypertensive disorders in pregnancy. Int $\mathrm{J}$ Reprod Contracept Obstet Gynecol 2016;5:4382-4. 